\title{
ENDURANCE OF THE SUBALTERN: A STUDY OF A THOUSAND SPLENDID SUNS BY KHALID HOSSEINI
}

\author{
Ghulam Yasin $^{1 *}$, Sajid Waqar ${ }^{2}$, Noveen Javed ${ }^{3}$, Ahmad Naeem ${ }^{4}$ \\ ${ }^{1 *}$ Lecturer in English, Higher Education Department, Punjab, Pakistan; ${ }^{2}$ Assistant Professor, Department of English, \\ University of Sialkot, Pakistan; ${ }^{3}$ Assistant Professor, Department of English Linguistics, The Islamia University of \\ Bahawalpur, Pakistan; ${ }^{4}$ Lecturer, Department of English Language and Literature, Gomal University, D. I. Khan (KPK), \\ Pakistan. \\ Email: ${ }^{1 *}$ ghulam.yasin@ scholars.usindh.edu.pk, ${ }^{2}$ sajid.waqar@uskt.edu.pk, ${ }^{3}$ noveens@yahoo.com, ${ }^{4}$ anaeemk@ hotmail.com \\ Article History: Received on $22^{\text {nd }}$ May 2021, Revised on 30 ${ }^{\text {th }}$ May 2021, Published on $5^{\text {th }}$ June 2021
}

\begin{abstract}
Purpose of the study: The present research aims to explore the oppressed and marginalized Afghan women who are made subaltern socially and religiously. It further reveals the ability of women to endure the violence and to create the vision of women empowerment through their suppressed bodies.
\end{abstract}

Methodology: The primary data of research relies upon the text of A Thousand Splendid Suns by Khalid Hosseini (2007). Further, it has also been collected from secondary sources like articles and reviews mentioned in the reference list. The selected text is analyzed under the theoretical framework of the theory of subaltern by Spivak (1988), utilizing the content analysis.

Main findings: The study dismantles the struggles of marginalized women for their survival and to free them from the suffocating chains of repression and violence. Nana, Mariam, and Laila being the subaltern know the word 'Endurance' while living in dilapidated social conditions. They show the degree of resistance and then also unite to stand against societal prominence. Mariam- the harami, sacrifices her life for Laila and Laila becomes the voice of her coming generation who can challenge the subaltern attitude and will speak loudly.

Application of this study: Utilizing the theory of subaltern by Spivak, this research answers the question "Can the subaltern speak?" as 'Yes'. It brings a message if the subaltern group combines and stands against the unjust norms, they will no more remain a subaltern and will be applicable for academicians and researchers as well.

Novelty/Originality of this study: The study is distinctive because it explores the literature that portrays the stories of almost every home and corner of the world. Despite passing phases of woman's rights, the female gender is still being suppressed. It also unveils how gender inequality, poor and gender-biased educational systems, the justice system, and constrained or child marriages are being practised.

Keywords: Endurance, Marginalization, Patriarchal Society, Subaltern, Violence.

\section{INTRODUCTION}

Khalid Hosseini is an Afghan-American doctor and a fictional author. His different style in writing makes him prominent in the world of literature. The very first novel by Hosseini The Kite Runner (Hosseini, 2003) got fame and became New York Times bestseller novel. This novel describes the class system during the Taliban rule in Afghanistan. Further, it also portrays the conflicts between Shia and Sunni and develops how a particular group or a community like Hazara is made a subaltern in their natural conditions. Then the second novel A Thousand Splendid Suns (Hosseini, 2007) also got popular, but this time, the subaltern figures were Afghan women instead of any community.

According to (Kazemiyan, 2012, p. 05), the depiction of women in the novel "[...] encourage the Western readers to determine their perception of Afghan women". The female characters portrayed by Hosseini (2007) are the subaltern or marginalized characters. The social constructs of the patriarchal society make the women marginalized, submissive and subordinate to their men. (Ramphiphatthamrong, 2020, p. 52), argues that "Afghan women have been socially constructed to rely on men and to obey their commands". They are restricted to wearing a burqa either they like it or not, Mariam mentions, "The padded headpiece felt tight and heavy on her skull [...] and she did not like the suffocating way the pleated cloth kept pressing against her mouth"(Hosseini, 2007, p. 71). Their mobility and communication with society were also almost forbidding. Rasheed warned Mariam, "that she was not to come down until the visitors had left" (Hosseini, 2007, p. 80). The women are marginalized inside the houses and are not allowed to go outside with their men or without their permission, "You will stay inside your homes at all times. It is not proper for women to wander about the streets" (Hosseini, 2007, p. 271). Further, they are subaltern based on their gender and body structure, a young man describes the difference; "God has made us differently, you women and us men. Our brains are different. You are not able to think we can" (Hosseini, 2007, p. 355). This sort of marginalization creates the image of how women become subaltern and how they are further exploited by their men. 
It is the union of cultural traditions, system, and patriarchal society that keeps their women in a dependent position. In Afghan culture, the women are seen as subaltern and others as well. They are even not involved in the decisions being made about them. According to (Ahmad, Mehmood, \& Dar, 2019) the novel also talk about the restrictions to keep the women marginalized, "[...] having their mobility constrained, being barred principally from practising their lawful, societal and political entitlements" (p. 59). In such dark conditions, a couple of female characters shine with endurance and resistance to create hope of good days for all other subaltern classes. (Rehman, \& Anwar, 2020) also mention that Hosseini "manifests a resistance to the rampant gender patriarchal norms that go against the basic rights of women to survive" (p. 121). It is because "Not all Afghan women are bound to remain oppressed, and that the women behind the veils have inner lives and aspirations" (Çevik, \& Töngür, 2019, p. 57).

\section{Factors Involved In Keeping The Women Marginalized}

To keep the women under subordination, their men assert violence to control them. The women are being harassed, beaten, and killed in every corner of the world. The most common terms used for gender violence are 'intimate partner violence, 'spousal violence', 'domestic abuse', 'domestic violence, ' and so on. Different critics, authors, and female activists have now taken up the issue very seriously, but the situation is still very drastic. (Terry, 2014, p. 1) mentions the report of United Nations: "Up to 70 percent of women and girls will be beaten, coerced into sex, or otherwise abused in their lifetime". Further according to Asha-Rose Migiro (Women, 2010, p. iii), Deputy Secretary-General United Nations, the women are compelled to endure violence almost in every society and in every part of the world, and "Women are being beaten, trafficked, raped and killed. These human rights abuses inflict great harm and suffering on individuals".

Patriarchy is the other influential factor that keeps women subjugated and marginalized. It is the "institutionalization of male dominance" and the social system that is "enforced through violence and the threat of violence". This kind of social system is built up and later run by authoritative men. In this system, "women, children, other men, and nature itself is dominated". These powerful men further keep all other institutions like culture, politics, and religion under their strong control. The women, in particular, are subjugated and placed in a subordinated position in such systems. Their mobility is restricted and their dependence upon their men is increased after monopolizing the social institutions (Yaqoob, 2018, p. 2).

\section{Major Concern of This Research}

This research majorly focuses upon analyzing the attitudes, beliefs, and circumstances in which the female characters grow, act, and are forced to act. In this regard, the researcher focuses upon the analysis of three female protagonists of the selected novel who are treated as a subaltern in the patriarchal society of Afghanistan. After the long endurance of suppression and repression, the subalterns begin to resist. They want to free themselves from the clutches of patriarchy and prove that the subaltern can speak and it is the right time now.

\section{The objective of the research}

1. To explore the oppressed and marginalized Afghan women who are made subaltern socially and religiously.

2. To reveals the ability of women to endure the violence and to create the vision of women empowerment through their suppressed bodies.

\section{METHODOLOGY}

The present research presents the content analysis of a single novel A Thousand Splendid Suns (Hosseini, 2007). It is because the method of Content analysis identifies the content (of the text) and characteristics of the author. The contents of this selected novel bring female characters on the scene who have been pushed in the group of the subaltern. The analysis of the selected text is connected to the behaviours of the patriarchal society which the female characters endure throughout their lives. The research mainly focuses upon three female characters Nana, Mariam, and Laila, and their attitudes towards the male-dominated society which makes them subaltern.

\section{Theoretical Framework}

The compound word 'Subaltern' has been taken from the Latin language. Here 'sub' means "below or under" whereas the word 'alter' presents the connotation of "otherness or of Aeternus" (alternate). Further, it is used to define "subordinate, lower-ranking and for the inferior individuals". In the middle ages, the term was used for the "vassals and peasants." Later, during the era of 18th and 19th century, the term "subaltern" was denoted as "Military term." In the Military context, it was applied to military commissioned officers "below the rank of captain" (Ghafoor,\& Farooq, 2020). In the concept of "subaltern", there always exists a complex relationship between power and subordination. This subordination neither accepts the rule of power wholeheartedly nor adopts the dominant standpoint of view as expressive of its own identity. 


\section{Theory of Subaltern}

According to the theoretical framework, this research paper is based on the concept of Subaltern presented by Spivak in her theory 'Can the subaltern speak'? Spivak is a very influential critic in South Asia's post-colonial studies. It is her billion dollars question, "Can the subaltern speak?" that has brought the oppressed and suppressed classes on the scene. She answers the question as 'No'. It is because "when the subaltern speaks, s/he remains no more subaltern". The subaltern class or gender is also considered the 'others' and the theme of 'otherness' is the major theme in modern fiction. The marginalized characters always struggle and keep on fighting from corner to the centre (Joyia, 2017, p. 100).

The theory of 'Subaltern' was also presented by Antonio Gramsci (1891-1937) in his article 'Notes on Italian History'. According to Gramsci (Ghafoor, \& Farooq, 2020, p. 43), "Subaltern are those classes which are not allowed to play the significant role in the formation of power that curb them, instead of it, they subjugate them". Further, the Subalterns remain dependent upon the 'the dominant class'. They even have no freedom to speak and to raise the voices for their rights. Gramsci further believes that the subalterns belong to the underclass group in a social order on whom the upper class shows its hegemonic influence. Subaltern is a term that may be applied to any class, caste, gender, race, language, and culture.

\section{Strict Rules for Women during the Taliban Period}

The women in Afghanistan have been kept silenced with the Taliban's introduction and imposition of laws. Hosseini develops through this novel that such laws are implemented only to keep control over the subjugated gender and people. (Chitnis, 1998, p. 21) claims in this regard that: "writing in the context of patriarchal theoretical notions, violence acquires overtones of control and will". (Hosseini, 2007, p. 248) narrates the grim details of the women's depressed conditions. There were certain to control the subalterns and of course, those surround the women's personal and social life merely. At the social level, the women were not allowed to move freely outside their homes, and "You will stay inside your homes at all times. You will cover with burqa when outside. If you do not, you will be severely beaten".

Further at the personal level, Afghan women are also being deprived of natural and personal rights. The next rule commands "Cosmetics are forbidden. Jewelry is forbidden. You will not wear charming clothes". Their public lives are also completely banished as per the desires of the patriarchs." You will not speak unless spoken to. [...] You will not laugh in public. If you do you will be beaten". They are even being observed minutely and are even not allowed to do things at a minor level as well. There are hard punishments against the fulfilment of some minor desires for the women like "You will not paint your nails if you do you will lose a finger". Getting education by every person is considered the basic right without considering the gender but here Hosseini mentions that "Girls are forbidden from attending school. All schools for girls will be closed immediately". They are only the subaltern of the day and dependent who is bound to depend upon their dominated men and "Women are forbidden from working" (Hosseini, 2007, p. 248-49).

Hosseini makes it clear that norms and values connected with the culture are also designed by the patriarchal societies that help them to keep them dominated. Further, the World report on violence and health (Krug, 2002, p.3) also mentions the facts: "As long as there has been violence, there have also been systems - religious, philosophical, legal and communal [...] all have made their contribution to this defining mark of civilization". Further according to (Chaudhary, 2020), such strict rules "finally led them to voiceless deaf and dumb puppets as told Gayatri Chakraborty Spivak" (p. 5495). (Khan \&Qasim, 2017) also argue that Hosseini relates the worst conditions of Afghan females with Taliban like other different authors. But history tells a different story that the tribal rules and patriarchy do exist long before the rule of the Taliban those suppress the Afghan women equally. Their culture and norms deprived the Afghan women of "their right to work, education, health, and independence — all of this made worse by three decades of war, displacement, and anarchy" (p. 133).

\section{Endurance of the Subaltern}

Endurance is the ability of an organism to exert itself and remain active for a long period, as well as its ability to resist, withstand, recover from, and have immunity to trauma, wounds, or fatigue. Endurance training can harm the ability to exert strength unless an individual also undertakes resistance training to counteract this effect (Hickson, 1980). Further, "[...] we rejoice in our sufferings, knowing that suffering produces endurance, and endurance produces character, and character produces hope." Hope is essential to us; without hope, we do not need a saviour, and thus no need for God. The Bible tells us that one of the only ways to produce hope is by enduring (Simeon, 2002).

Hosseini has derived its title from the poem composed by the seventeenth-century poet Saib-e-Tabrizi. The novel discusses the history of three decades like anti-Soviet jihad, civil war, and finally the gender hardships of the Taliban era. This sort of history presentation has been done from the perspectives of two women Mariam and Laila. Further, Khalid portrays the painful reality of women's conditions in the patriarchal society through the female characters at the broader level. (Sapkota, 2020) mentions Hosseini for his skill of " [...] displaying the reality of gender roles in Afghanistan through Nana, Mariam, Fariba, Laila, Aziza, and other minor female characters" (p. 55). He probes the issues like gender inequality, poor and 
gender-biased educational systems, the justice system, and child marriages. In this novel, Hosseini comes forward as an orientalist author who tries to give voice to the subaltern unheard characters.

The novel opens thoughtfully and sets the mood of the upcoming events, language, and incidents. It describes the violence and injustice that the female characters have to endure to survive in the patriarchal society. The novel's opening line tells the story of endurance for the female gender: "Mariam was five years old the first time she heard the word harami ... This is my reward for everything I've endured An heirloom-breaking, clumsy little harami” (Hosseini, 2007, p. 01).

The study focuses upon three female characters Mariam and Laila who endure and resist for their survival. Nana belongs to the subjugated family, though she talks about the follies of the patriarchal system she endures the suppression with courage and silence. Her Husband Jalil is known a generous with his four wives but he is not having a single penny for Nana. Sapkota (2020) mentions Jalil even "He did not, however, provide Nana with any aid in conceiving but built her a rat-hole, Kolba" (p. 56). Second, Mariam is called "harami" and she is bestowed with such titles right from her childhood. It seems that she is a separatist and is not considered a part of any social activity. Once she endures the violence courageously and silently but later she not only raises the voice but physically fights against the patriarchal norms. Laila is the third female character who endures and resists strongly. She joins hands with Mariam in the fight against brutal patriarchy. She becomes the strength of Mariam for their common interests and freedom. According to (Bharwani, 2011), the novel presents various ways of violence the women endure and it "[...] makes their lives a chronicle of constant violence". Further, it also describes" bonds of a common identity are formed by the women to combat the violence that they face jointly" (p. 237).

The significant fortitudes of Mariam, Laila, Naina, and other Afghani women describe their place in the war-torn Afghani society. This is the story of Mariam and Laila and their strength to endure domestic, physical, sexual, and social violence. Naina tells Mariam: "It's our lot in life, Mariam. Women like us. We endure. It's all we have" (Hosseini, 2007, p. 18). This damage may occur either by the never-ending war in Afghanistan or by the social system being run by the patriarchal authorities. According to Yaqoob (2018), the women are not permitted to have their presence in public places and are bound to remain in their four walls under the clutches of their men. They endure violence just for "[...] not cooking his meal of choice, not having borne sons as per his strong desire, making attempts to go out without permission, or sometimes simply because he is in a bad mood or is unhappy" (Yaqoob, 2018, p. 6).

In patriarchal societies, women always sacrifice their freedom of life, and the portrayal of female characters by Hosseini is very suitable for the purpose. They can neither live according to their desires nor decide about their own lives. They are the puppets who always play in the hands of male characters. According to (Rehman\& Anwar, 2020), these female characters are "born for domestic chores and household responsibilities. Outside these assumed limitations, women had no identity" (p. 116). First, Jalil's character is the man with "three wives and nine children, nine legitimate children" (Hosseini, 2007, p. 5). Second, there comes a widower looking desperately for the obedient wife, Rasheed. Hosseini describes almost every female character suffering from the tyranny of the male dominancy and as the subjects to their men. Mariam remembers the words of her mother at the time of her constrained marriage that "Like a compass needle that points north, a man's accusing finger always finds a woman" (Hosseini, 2007, p. 7).

After the death of Naina, Though Jalil brings Mariam into her home, she is not acceptable to anyone as being a 'harami' or an illegitimate child. To get rid of her, his family decides to arrange the fifteen-year-old Mariam marriage to Rasheed, a widower, a carver of stone, and about forty years old. "Mariam saw a tall man, thick-bellied and broad-shouldered, stooping in the doorway. The size of him almost made her gasp" (Hosseini, 2007, p. 48). Mariam looks like a younger daughter of Rasheed while standing beside him. She is being married against all her wills and wishes, but she could do nothing except accepting this unnatural and unlawful act of marriage.

Hosseini postulates patriarchal Afghani culture where marriage isn't linked with romance or choice of the girl, but it is like a deal of the male members. Mariam wants to protest against this constrained marriage or wants to refuse this marriage, considering it her religious and human right, but no one hears her. She is a subaltern, and her voice dies under the four walls of a mudroom where she is locked till the day of her marriage. "She, Mariam, was an illegitimate person who would never have a legitimate claim to the things other people had, things such as love, family, home, acceptance" (Hosseini, 2007, p. 6). Hosseini advocates the horrors of constrained marriages and it results in no more than the destruction of human lives.

Khalid Hosseini also raises a voice against the constrained marriages being held commonly in male-dominated societies. First, the marriage of Mariam and later of Laila is the true example of this catastrophic situation. Mariam was never interested in this relationship and wanted to live her life. She called for help, but her voice couldn't jump out of the walls. Hosseini portrays both the female characters "as a piece of man's patrimony". The concept was already presented by De Beauvoir in 1949. According to (De Beauvoir 2011), the female entity" is losing herself, female is lost" (p.3). The patriarchal norms are crushing their entity and identity and at this stage," she doesn't possess anything, female is not raised to the nobility of a man; she is a piece of man's patrimony, first her father's and after that her husband's" (De Beauvoir, 2011, p.93). The male dominant societies are utilizing them as the goods of trade in the name of marriage. 
The refusal of Mariam before the wedding becomes a curse for her and adds more to her sufferings. This marriage with the dreadful tempered Rasheed turns into a significant physical and psychological punishment for her body and soul. This marriage has never been the messenger of good fortune, but it brings the hellish gloom and torture to endure. Kazemiyan(2012) argues about her married life: "Mariam still shivers with fright when she is exposed to the outrage of Rashid. It is the fear of the goat, released in the tiger's cage" (p. 59). Hosseini criticizes the concept of woman as personal property of the male through the relationship of this newly married couple. Chaudhary (2020) observes that "With the premise that a woman must endure the stress of discomfort, rejoice and experience life's problems by managing her feelings and needs, rather than confronting or questioning them" (p. 5499). After some time, he uses verbal abuse and physical violence against his spouse and it becomes her fate to endure it silently.

Her married life is filled with the "fear of his stifling mood, his volatile temperament" and mostly "he would resolve with punches, slaps, kicks" (Hosseini, 2007, p. 97). Once Rasheed did not like the meal and forced the naïve "to eat the pebbles" (Hosseini, 2007, p. 102), and she was bound to obey. Resultantly she lost her teeth but was not in a position to refuse the commands of her master. Hosseini criticizes the traditional mindset of the patriarchal society that "A good wife must be submissive and belong with the possessions of her husband" (Ramphiphatthamrong, 2020, p. 53). The women even do not keep the right of protesting or saying few words in their favour, but they are bound to obey because they are the subaltern. Based on these facts, Yaqoob (2018) calls these women "as domestic slaves [...] which relegates women to subordination and positions them as vulnerable; hence, they are easy victims of all types of violence" (p. 11). Against all the trials, Mariam can only think, "how women like us suffer, how quietly we endure all that falls upon us" (Hosseini, 2007, p. 90).

Further Hosseini also raises their voice against the sexual harassment or violence inflicted against the subaltern women. Rasheed practices this sexual violence to show his manliness. (Hosseini, 2007, p. 69) portrays it "Mariam began shivering. His hand crept lower still, lower, his fingernails catching in the cotton of her blouse. I can't, she croaked". (Rani, 2020) argues that "For all his brutal treatment, Mariam used only one suggestion her mother taught her Endure" (p. 668). Hosseini brings about the classical Orientalist characterization of Afghani Muslim men by presenting them as archetypes of sexual atrocity and monsters. He has adopted the same Orientalist strategy by introducing Rasheed as a sex-obsessed beast. "The pain was sudden and astonishing. Her eyes sprang open. [...] Mariam stared, wide-eyed, at the ceiling above his shoulder, shivering" (Hosseini, 2007, p. 69).

According to (Rani, 2020, p. 667) the love of Rasheed for her wife Mariam later turns to hatred because "she can't give him a boy child" and Later "Rasheed is completely immune to the terrible heartbreaks endured by Mariam due to her continuous miscarriages". Hosseini seems to challenge the traditional patriarchal concept that "A woman's value in Afghanistan has often been measured by her ability to bear children, especially boys" (Ramphiphatthamrong, 2020, p.55). Further, he also brings forth the real reason for the complication. He shifts the responsibility towards the dominated men and their society. The crisis is because of her early marriage. At an early age, she is impregnated. Having the very first shower after the marriage night, she finds "there was blood and she was screaming" (Hosseini, 2007, p. 88). It is also mentioned in Mary O'Brien's 'The Politics of Reproduction' that men control women's reproductive process through medical, social, and cultural structures. She argues that women would reclaim this control and positively affirm the role of mothering (O'Brien, 1981, p. $\underline{667)}$.

In this tale of sufferings, there comes a twist with the arrival of another female character, Laila. She is younger just fourteen years of age and coming from the city. Her parents have been shot dead in a rocket fall at their home. She was pregnant after having a relationship with his lover Tariq and Rasheed very cunningly announces a false rumour of his death. In this way, Laila has no other option left except acknowledging the proposal of Rasheed. Chaudhary (2020) mentions, "Rasheed's only wish for a son leads him to entice Laila for marriage trap by taking the wrong advantage of her circumstances" (p. 5497). Once Rasheed was also pleased with her appearance of Laila and calls her "You ... are a Benz. A brand-new, first-class shiny Benz" (Hosseini, 2007, p. 216). She became the second victim of Rasheed's brutal desires and lost her importance with the birth of a girl Aziza. But there is a great difference in the approach of the two, Mariam and Laila. According to (Soraya, 2015), "Laila is a subaltern who dares to speak [...] Mariam is a traditional figure who is always silent in receiving Rasheed's abusive attitude" (p. 86).

For the last couple of years, Mariam was a subaltern and enduring every sort of violence alone physically, psychologically, and sexually. She even could not plan to strengthen herself against the dominant man. As a matter of routine, "Rasheed raised the belt and came at Mariam. At that point a shocking thing happened: The young female (Laila) trusted at him" (Hosseini, 2007, p. 146). Laila got success in diminishing the advancement of Rasheed towards Mariam. In this way, both the victims and subalterns come close to one another to raise voice against the male dominancy. In the first attempt, they planned to run for Peshawar in Pakistan, but again they became the victims of hard rules made by the Taliban. "It is not proper for women to wander about the streets. If you go outside, you must be accompanied by a mahram, a male relative" (Hosseini, 2007, p. 248). Though they could not break the tradition of the patriarchal society, now they have got the answer to the question 'Can Subaltern speak' in 'Yes'. 
They were again in hands of the masterly husband and the sufferings again began to endure: "Then she was being dragged by the hair. Hair was ripped off from Laila's scalp, and her eyes watered with pain (Hosseini, 2007, p. 240). Laila was fighting for the freedom of her coming generation. She considered it a last fight against the patriarchal system, and finally, "He let go of Laila's hair, and she felt the toe of his shoe connect with her left buttock" (Hosseini, 2007, p. 240). The noise of beatings and cries are common happenings in this house. Mariam is the embodiment of endurance, and Rasheed is the real embodiment of violence. He was out of his nerves and was beating Mariam wildly in his anger: "There was blood on his hands, blood on Mariam's face, her hair, down her neck and back" (Hosseini, 2007, p. 240). The detailed grim descriptions by Hosseini present the real picture of the violence the female characters are to endure within the jail-like home. Mariam and Lail join together to remain no more the subaltern. The subalterns have decided to speak and even fight for their rights.

Finally, Laila comes to know that her lover Tariq is alive, and they both meet face to face. By considering it the real assault over his honor, Rasheed becomes out of control; "Without saying a word, he swung the belt at Laila", but this time the subalterns Mariam and Laila become the strength of each other to stop the brutal bull in his full rage. They fight manly and rescue each other; "She saw fingers clawing at Rasheed's face, chipped nails digging into his jowls and pulling at his hair and scratching his forehead" (Hosseini, 2007, p. 308). Rasheed strikes Laila and endeavours to choke out her. The danger presented to the life of Laila provides Mariam with courage and power. She observes that Laila is neither battling nor moving anymore but is turning blue. She has no other option except using the untested weapon - 'violence against violence' - and she does this. Violence is the device that has consistently been utilized to control Mariam, and she also chooses a similar method. She is well aware that no other method will work in such odd circumstances. Ann Jones (Bharwani, 2011, p. 298) mentions that "People who go through it (violence), as victims or as witnesses, learn (among other things) to fear violence, to avoid violence at all costs, or to be violent".

Mariam has always been a subaltern; always weak, submissive, voiceless, and enduring. (Yaqoob, 2018, p. 8) describes her life that "These women are like domestic animals, kept and confined within a domestic sphere for the service and pleasure of men". Now she wants to be heard, wants to attain the identity of a savior even at the cost of her own life. Moreover, the love of Laila for a love seeking girl becomes the strength, Mariam "[...] tightened her grip around the shovel's handle. She raised it. She said his name. She wanted him to see. Rasheed" (Hosseini, 2007, p. 310). She hits the shovel forcefully against his temple and this assault is the bursting of her repressed life. (Ramphiphatthamrong, 2020, p. 59) also argues that "Metaphorically, the shovel might represent Mariam's repressed emotions and the psychological stress experienced throughout her life".

After the continuous endurance of the sufferings, there comes a change in the character of Mariam. Now she is decisive and determined. She has always seen unkindness, hatred dislikes but this time, "In Rasheed's eyes she saw murder for them both" (Hosseini, 2007, p. 311). Now she cannot afford to be passive, but she has to complete what she has begun. It is a need for the peaceful living of Laila and her family. Mariam assembles up all the power she has and tosses one last rage upon Rasheed. She decides immediately despite being indecisive, like in her early life, "It occurred to her that this was the first time that she was deciding the course of her own life. And, with that, Mariam brought down the shovel" (Hosseini, 2007, p. 311). It is the development in her character that she decides to die with honour instead of dying in the hands of cruel Rasheed as a subaltern.

When a female like Laila is subjugated or is not heard, she grapples and reacts against the dominant agency. The subaltern theory is itself presents a reaction against the colonial forces. Though the medium of Language in written is the key source to present ideas through texts "gestures, actions, the facial expression of body language also convey the feelings and the messages of the subaltern". Spivak claims "subaltern does not remain, subaltern when s/he speak". These are the subalterns who come forward to speak, protest and even show their annoyance utilizing killings (Ghafoor, \& Farooq, 2020, p. 54). The killing of Rasheed brings a new beginning for Laila and others but Mariam is to sacrifice.

Mariam is arrested by the Taliban police and puts to the narrow cells. She is to appear in court. Once at the time of her forced marriage, she was subaltern and helpless, but now she advocates her case and explains her position. She boldly tells the court about her self-defense: "I admit to what I did, brother, Mariam said. But, if I hadn't, he would have killed her" (Hosseini, 2007, p. 322). According to Sapkota (2020), She pleads that "Rasheed will have killed them all if she had not struck him first, but the Judges didn't believe her" (p. 60). Hosseini also seems to criticize the judicial system of the day. It was a strange court. "There was no legal counsel, no public hearing, no cross-examining of evidence, no appeals" (Hosseini, 2007, p. 321). Finally, the court decides the death sentence for Mariam, but she looks calm and peaceful after a long endurance and fights against the patriarchal norms, domestic and gender violence, psychological terror, and discrimination. According to (Rehman \& Anwar, 2020), "Mariam does not repent of her action. She takes it as revenge to the entire society of gender discrimination" (p. 123). It seems that she is satisfied with this end of her life "It was not regretted any longer but a sensation of abundant peace that washed over her [...] This was a legitimate end to a life of illegitimate beginnings" (Hosseini, 2007, p. 341). 
Two female protagonists Mariam and Laila, in the novel A Thousand Splendid Suns teach themselves and also teach those around them to observe the life challenges as short-term. Initially, Mariam seeks calmness in her dreams "Mariam could see herself too, reflected in the brown of Jalil's eyes: her hair billowing, her face blazing with excitement, the sky behind her" (Hosseini, 2007, p. 21). On the other side, Laila teaches the other female characters to fight for the fulfilment of their dreams "the most important thing in her life, after her safety, was her schooling" (Hosseini, 2007, p.114). They both learn quickly that they are not able to overcome and even endure the sufferings of domestic life if they keep on fighting against each other. In this way, their unity becomes their strength, and they are prepared to fight their war within the four walls of their home in a broader scenario of Afghan war settings.

Though Mariam loses her life her sacrifice brings a strong message of hope for every woman being treated as a subaltern in the patriarchal system. Laila settles back in Kabul after some time and starts working for the welfare and education of girls. Sapkota (2020) describes that "Mariam's sacrifice provided Leila a sense of purpose in her life when Laila chooses to devote her life for the greater good of the society in Kabul" (p. 60).

\section{CONCLUSION}

The novel A Thousand Splendid Suns by (Hosseini, 2007) portrays how women's roles are perceived in a patriarchal society, within the four walls of their men's homes, in public places, or mainly in the context of being a woman. The lives of female protagonists Mariam and Laila are always in the process of struggles, journeys, and efforts, they want to enjoy the experience of freedom but are always trapped in the clutches of patriarchy. Rehman \& Anwar (2020) explain, "As Spivak puts a question that the male-dominancy does not tolerate representation of marginalized class and their voice is silenced not to be equal with the powerful class of a society" (p. 120). In the same way, the female characters portrayed by Hosseini are also not able to find their voices to be heard in the patriarchal society and system.

The female characters portrayed in A Thousand Splendid Suns (Hosseini, 2007) are mainly epitomes of the modern world because they face domestic and social violence bravely and keep on thinking about the use of conventional and unconventional methods to defeat the patriarchal repression and fight for their freedom. Further, They claim that without mentioning any gender, belief, or socio-economic conditions, all male and female have an opportunity to grow in life. Particularly Mariam struggles to seek freedom and love from someone throughout her life. She is alone, suppressed, and endures long-sufferings silently as a subaltern but she becomes bold and begins to resist after having the love of Laila. Considering the phrase by Spivak "Can the Subaltern Speak?", Hosseini maintains that the women are subaltern and marginalized by the patriarchal system. They can and will be able to 'voice out' only if they show courage and resistance along with the endurance of the calamities.

Female characters represented in the novel are victims, marginalized, and oppressed because of patriarchal ideologies. They are submissive, male-oriented, and passive but this study presents a new perspective of such subaltern characters. It contradicts the set beliefs that women are always born to endure the exploitation of the patriarchal mindset. It is proved through the development of the character of Mariam. In the end, Mariam represents the Afghan women who are not marginalized, passive, or subaltern. She neither remains the "male-oriented" nor "victim-oriented" construct of the "Third World" women (Ramphiphatthamrong, 2020, p. 60). She has the courage, determination, and power to decide. She is not the subaltern, she can speak and she has the answer to every brutal act of the patriarchy.

The research stresses the need for female bonding, only they can encourage each other to break the dominant norms of patriarchy. Once Mariam is the representation of a typical Afghan woman, she is submissive, afraid, and passive but the company of Laila makes her strong and conscious about her strength and subjugation. The sharing of grief and pleasure, knowledge, and information teaches them about the need for gender equality. Further, the fortitude and commitment against the male dominancy in the developed character of Mariam is the consequence of this female relationship. Finally, a subaltern being changed to a strong and decisive female character. Importantly, this union enables them to break the shackles of social values, traditions, and customs all set by their male members. (Shameem, 2014, p. 64) argues that "women also seem to be internalizing the essentialist patriarchal customs which traps them further in the web of marginalization".

\section{LIMITATIONS AND FUTURE RESEARCH DIRECTIONS}

The research has been limited to Khalid Hosseini's single novel 'A Thousand Splendid Suns' (2007). The novel has been selected because it suits the major concern and theoretical framework of the research. Furthermore, the research is limited to three female characters. These female characters represent the subaltern community, endure the sufferings of patriarchy and finally present the message of women empowerment with their unity.

Considering the limitations of the research, the future research directions reveal that it may be done at a broader level by involving all the female characters, which may describe the better perspective of the issue. Furthermore, issues related to women's constrained marriages, education, and working may also be portrayed on the greater canvas. 


\section{AUTHORS' CONTRIBUTION}

1. Ghulam Yasin has conceived the idea and worked on developing the theoretical framework of the paper, data analysis, and interpretation.

2. Dr. Sajid Waqar has written the introduction and worked on extracting evidence for data analysis and literature survey.

3. Dr. Noveen Javed has worked on literature review and also contributed to data interpretation in the manuscript.

4. Ahmad Naeem has written the conclusion and worked on references and the overall formatting of the paper.

\section{REFERENCES}

1. Ahmad, M., Mehmood, S., \& Dar, S. R. (2019). Loss of self-identity of Afghan women: A third-wave feminist study of Khalid Hosseini's A Thousand Splendid Suns. Erevna Journal of Linguistics and Literature, 3(1). https://www.researchgate.net/publication/344217828

2. Bharwani, M. (2011). Changing Diasporic Representations: An Interrogation of the Responses to the Trauma of Violence in Select Writers Of the South Asian Diaspora Post 2001. PhD Thesis. SNDT Women's University Mumbai.

3. Çevik, Y. \&Töngür, A. N. (2019). The plight of marginalized women in Khaled Hosseini's a thousand splendid suns in 'the third world feminism'. The Journal of International Social Research. 12(66), 56-64. https://doi.org/10.1 7719/jisr.2019.3559

4. Chaudhary, P. (2020). Women Resistance and Power Relation in Khaled Hosseini's A Thousand Splendid Suns. Journal of Xi'an University of Architecture \& Technology, xii(iv), 5493-5502.

5. Chitnis, S. (1998). Violence against Women, Women against Violence. Delhi: Pencraft International.

6. De Beauvoir, S. (1949/2011). The Second Sex. Translation. Borden, C., \&Chevallier, S. Introduction by Sheila Rowbotham. London: Vintage Books, 2011 (1st Ed. 1949).

7. Ghafoor, S., \& Farooq, U. (2020). Can Subaltern Be Heard: An Analysis of the Kite Runner and the Thousand Splendid Suns by Khalid Hosseini: Can Subaltern Be Heard. International Review of Literary Studies, 2(1), 42-56. Retrieved from https://irlsjournal.com/ojs/index.php/irls/index.

8. Hickson, R. (1980). "Interference of strength development by simultaneously training for strength and endurance over a long period". European Journal of Applied Physiology and Occupational Physiology, 45, 2-3. https://doi.org/10.1007/BF00421333

9. Hosseini, K. (2007). A Thousand Splendid Suns. London: Bloomsbury Publishing.

10. Hosseini, K. (2003). The kite runner. Penguin.

11. Joyia, M, I, et al. (2017). Courageous Women: A Study of Resilience of Women in Khaled Hosseini's Novel A Thousand Splendid Suns. Language in India, 17(1), 98-108.

12. Kazemiyan, A. (2012). A Thousand Splendid Suns: Rhetorical Vision of Afghan Women.M.A. Thesis. Canada: Department of Communication, University of Ottawa. Retrieved from https://www.researchgate .net/publication/277750156_A Thousand_Splendid_Suns_Rhetorical_Vision_of_Afghan_Women

13. Khan, U. M.,\& Qasim, M. (2017). Feminist Politics of Representation: Portrayal of Afghan Women in Khalid Hosseini's A Thousand Splendid Suns. Journal of Applied Environmental and Biological Sciences, 7 (9), 127-136.

14. Krug EG et al., eds. (2002). World report on violence and health. Geneva: World Health Organization. Retrieved from https://apps.who.int/iris/bitstream/handle/10665/42495/9241545615 eng.pdf?sequence=1

15. O'Brien, M. (1981). The Politics of Reproduction. New York: Routledge.

16. Rani, E. (2020). Feministic Perspectives of Afghan Women in Khaled Hosseini's A Thousand Splendid Suns. A Journal Of Composition Theory, xiii(iii), 665-669.

17. Ramphiphatthamrong, T. (2020). Representations Of Afghan Women In Khaled Hosseini's Novels: The Kite Runner, A Thousand Splendid Suns And And The Mountains Echoed. Thesis. Chiang Mai University. https://www.researchgate.net/publication/343346053

18. Rehman, M. S., \& Anwar, S. (2020). Disruption of the Stereotypical Gender Construction through Afghan Women's Voices in Khalid Hosseini's A Thousand Splendid Suns. Central Asia, 86 (summer), 115-125. Retrieved from https://www.prdb.pk/article/disruption-of-the-stereotypical-gender-construction-through-4738

19. Sapkota, B. (2020). Ideological Essentialization of Afghan Women in Hosseini's A Thousand Splendid Suns. The Batuk, 6(1), 55-62. https://doi.org/10.3126/batuk.v6i1.32628

20. Shameem, B. (2014). Living on the Edge: Women in Khaled Hosseini's A Thousand Splendid Suns. Research Journal of English Language and Literature, 2(4), 62-66. https://www.researchgate.net/publication/330514596

21. Simeon, A. W. (2002). The Roots of Endurance. Wheaton. Crossway Books.

22. Soraya, S. (2015). The Subaltern Voice in A Thousand Splendid Suns by Khaled Khosseini. Lingua Cultura, 9(2), 81-87. https://doi.org/10.21512/lc.v9i2.827

23. Spivak, G. C. (1988). Can the subaltern speak? Marxism and the interpretation of culture. C. Nelson and L. Grossberg. Urbana, University of Illinois Press, 271-313. https://doi.org/10.1007/978-1-349-19059-1_20 
24. Terry, M. (2014). Applying the Social Ecological Model to Violence against Women with Disabilities. Journal of Women's Health Care, 1-8. https://doi.org/10.4172/2167-0420.1000193

25. United Nations (1993). Declaration on the Elimination of Violence against Women. Report. Proceedings of the 85th Plenary Meeting, United Nations General Assembly, Geneva, 20 December 1993.

26. Women, W. (2010). Handbook for Legislation on Violence against Women. Report. New York: United Nations publication. Retrieved from https://www.un.org/womenwatch/daw/vaw/handbook/Handbook\%20for\%20legislati on\%20on\%20violence\%20against\%20women.pdf

27. Yaqoob, M. (2018). Narratives of Confession: Religion and Patriarchy in the Fiction of Shahrazad Hosseini. Pakistan Journal of Women's Studies, 25(2). https://doi.org/10.46521/pjws.025.02.0043 